(13) R. C. Smith \& H. C. Howard, J. Am. Chem. Soc., 59, 234 (1937).

(14) H. Meyer \& H. Bandnitz, Ber., 63, 2010 (1930).

(15) F. Fischer, K. Peters \& W. Cremer, Brenn. Chem., 14, 184 (1933).

（16）舟阪洨，横川親雄，工化誌，印刷中。

(17) F. Fischer \& H. Schrader, Ges. Abh. Kennt. Kohle, 5, 530 (1920).

(18) F. Fischer \& H. Schrader, Brenn. Chem., 3, 66 (1922).

(19) E. Rose \& M. W. Lisse, Ind. Eng. Chem., 9, 284 (1917).
(20) W. Fuchs \& J. Sebelien, W. Fuchs: “Die Chemie der Kohle," s 51, Berlin (1931).

(21) P. Erasmus, "Über die Bildung u. der Chem. Bau der Kohlen", Stuttgart (1938).

(22) L. H. Hawley \& E. E. Harris, Ind. Eng. Chem., 24, 873 (1930).

（23）賀田立二，燃研報告，第10号。

(24) E. Berl, A. Schmidt \& H. Koch, Z. Angew. Chem., 43, 1018 (1930).

(25) E. Berl \& A. Schmidt, Ann.,493, 97 (1932).

(26) 舟阪洨，橫川親雄，工化誌，投稿中。

(27) E. Donath \& A. Lissner, Brenn. Chem., 3, 235 (1922).

\title{
On the Formation of Coal (III)
}

\author{
By Wataru Hunasaka and Chikao Yokogawa \\ (The Fuculty of Technology, Kyōto Univ.)
}

SYNOPSIS:-The authors assert the theory of coal formation from cellulose, against Fischer's theory of lignin origin, by the grounds of "artificial coal" experiments; (1) the oxidized product of the arificial coal from cellulose by permanganate shows the evidence of mellitic acid, (2) the cellulose coal has a lignin-like part by the usual rational analysis and (3) the artificial coalification of the mixture of lignin and cellulose suggests the mutual reactions during coal formation process, i. e., the expected importance of the composition in the vegetable debris as the original substance of coal formation.

\section{石油化学工業 の 進步 \\ 一昭和 27 年 8 月 15 日受理 一 \\ 三菱石油株式会社 山本 晴次}

要旨 筆者は, 主として米国に扣ける各種石油化学工業扣よびその製品について解說し，また最 近の原料消費高ならびに製品生花高のあとをたどつて有機化学工業界一の目覚ましい進出につい て述へ，併せて將来の発展に対する見透しを試みた。さらに，本邦に石油化学工業が行われる場 合の当事者の心がまえについても述へるとてろがあつた。

\section{（I）緒}

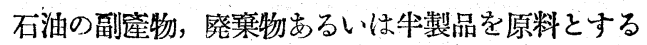
化学工業のはじまりは, 1919年米国ニュージャーシー 州カーバイド・アンド・カーボン社が石油源からアル
ロール製造を企業化したのにあるといわれる。しか し，観点を变えれば，1913年に完成した石油の熱分解 の工業化にあるともい得る。いずれにしてむ1910年 代であり，その歷史は約40年に過ざないか，その間石 
油工業の発澾と相件つて発展し，石油工業がその分野 飞高オクタン価揮材，高級潤滑油などを供給すると共 に, 石油化学工業は, 合成繊維, 合成ゴムその他各種 の有機化学製品を提供してきた。

特に今次大戦中，有穖原料の不足，特性物質の必要， 石油工業および有機合成工業の技術上の進步などによ りっこの石油を原料とする化学工業が急激に発達し,こ の工業を呼称するに石油化学工業 (Petrochemistry), その製品にペトロケミカルスなる語を生み出した活ど である。

一般には石油工業と石油化学工業とは区別され，前 者は從来の石油製品を生崖する工業，後者は石油を原 料とする石油製品以外のあらゆる製品を生虖する工業 と考えられているよらであるが，両都は，原料的にも， 技術的にも，まを裝置の点からいつても，切り離せな い関係にあり，特に原料供給面からいえば，石油工業 の発展淮步が石油化学工業を生み出したものである。

戦前，インォクタンの工業的生虖を実施していたわ が国の石油工業は，当時技綇面ではそれほど遅れては いなかつたのであるが，戦時中全く海外と隔絕されて いたため, 戦後石油化学工業の目覚末しい発展にわれ われは一驚を契した次第であり，これについては既に 譛権威により数多くの有能な紹介がなされ，ま意見 が述べられているので, 浅学の等者が本交を草するこ そは屋上茅を重ねる感があるが，幾分でも読者墸氏の 参考になれば幸である。

（II）石油工業の発展の理由，経過および趨勢

石油はその主成分が炭化水素であり, 量的にきわめ て豊富であるから，当然有機合成原料として早くから 着目されていたが，その組成が石炭タールに比して複 雜で単離が困難であつたため，戦前まではその利用が 限られ，大部分は単に燃料として使用されるに過ざな かつた。石油化学工業が高度に発澾した現在の米国に

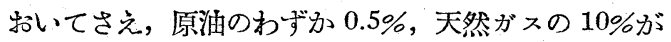
利用されているに過ぎないことを思觉ば，有機化学工 業資源としての石油がいかに量的に豊富であるからか がえよう。先に石油化学工業のはじまりは石油の熱分 解の工業化にあると述べたが，熱分解によつて副生し 最初は単に補助然料あるいは廃ガスとして燃燒廃寨さ れていた分解ガス中の反応性に富むオレフィン類の利 用に始まつたといえる。

石油が発見されてしばらくは灯油の時代が続き，揮 発油は発棄されていたが，ガッリン穖関の発明と共に 揮発油の時代となり，揮発油生雇のため熱分解法が発 達し，その際副生寸る分解ガスは初期の揮発油同様廃
㲤されていた。しかし, 合成化学の発展, 有機合成品 の需要の增加に徒い, この廃裹ガスが時代の花形の一 つそなり，オレフィンガス製造のみを目的とする裝置 さえ建設されている。石油化学工業発達の基礎は, 広 義には文化の隻步による有穖合成品の需要增加による 有機合成工業および石油工業の発達にあるが，狹義に は原料供給の面に抢ける後者に負うところ大である。

すなわち, 前述の石油分解ガスを利用して重合, 縮 合アアルキレーションなどにより高ォクタン価揮発油 を得んとして，まず必要ガスの純度を高めるためガス の精製法が発澾し，上記の合成法も相次いで発澾した。 また分解揮発油のォクタン価を高めんとして，触媒京 利用する接触分解,ついでリフォーミンク法が生れた。 これらの方法は，條件を選べば，パラフィン炭化水素 の脫水素環化,ナフテン族の脫水素反応か起り, 收得揮 発油中の芳香族含有量か㵔しく境すので，これにより 石炭ター儿源の不足を補うべく各種の純芳香族分離法 が完成された。

かくのごとく石油工業の発澾と石油化学工業原料源 の生艮は相件つたものであるが，上述の種々の方法の 万ち最龙注目されているものの 2,3 を挙げると, 天然 ガス，灯軽油などの分解によるェチレンガス製造涯と しては, Kellog 式, Lummas 式, T. P. C. 法, U. O. P. 式, ガス分離には吸着によるハイパーンープション 法, 芳香族生崖にはプラットフォーミング法, ハイド ロフォーミング法，T.P.C. 法など，芳香族分離には 共沸蒸溜涯, 抽出蒸溜法, 吸着による Arosorb 法, 選択溶解によるUdex 法など，また未完成ではあるが 最近注目を浴びている尿素, チォ尿素による正パラフ イン，オレフイン，ナフテンの分離法があるが，これ らについては既に紹介むされて抢り，また本小文の目 的とするところでないから割愛する。

有機化合物は大別して䥊式化合物と環式化合物に大

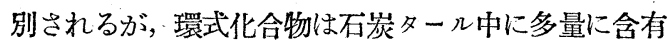
されて特り，環式化合物に関する有機合成工業のほと んどすべてはこの石炭タールを母体としていた。一方

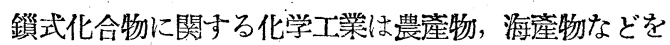
母体とする酸酵工業，油脂工業，繊維工業に過ぎず， 原料に制的され，その発展る遅々たるものであつた が，戦前いわゆる石炭液化法が発明されるに及んで飛 躍的な発展を逐げんとしていた。

石炭ター几工業, 石炭液化工業を含めて石炭化学工 業と総称するならば，これはドィッに㧤いて発展した ものであり，これに対するものが米国で発展した石油 化学工業である。その分野は鏝式化合物，環式化合物 
のみならず，水素，アムモニア，硫安にまで及び，そ の製品は無穖化学以外のあらゆるものに及んでいると いつても過言ではなく，いまや石炭化学工業にとつて 代わらんとしつつある現状である。

事実米国に挍いては，1945年度の全脂肪族化学製品
400 万 $\mathrm{t}$ の約 50\%が，また 1950年には約 600 万 t の ち約70\%が石油化学製品であつたが，数種の化学製品 の生荤高と，そのうち石油を原料とするものの割合を 示せば，第1表のと抽でる。

なお，最近では全化学製品の約 $25 \%$ か沰油化学製品

\section{第 1 表 1950年米国主要化学製品量亡石油化学製品の比率}

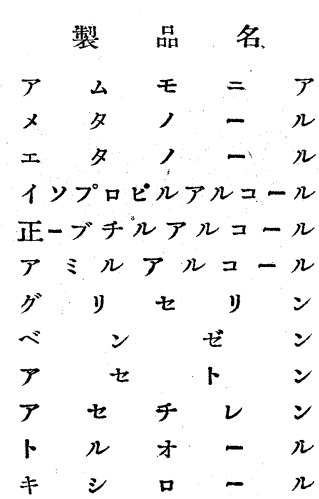

1950年度推定
生產量 $($ 万 $\mathrm{t})$
180
45
66.5
39.4
6.7
0.77
10
63.5
21.8
16.8
23
19.5

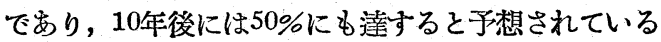
が，その資本增加，生蓙量墂加の跡と今後の予想を第 2 に表示す。

\section{第 2 表 石油化学工業資本金および生産高}

\begin{tabular}{|c|c|c|c|c|c|c|c|}
\hline & 年 & & & 1940 & 1945 & 195 & 1960 \\
\hline & 本 & 金 & （億ドル） & 3.5 & 10 & 2 & 80 \\
\hline & 成 & if & (万 $\mathrm{t})$ & 182 & 455 & 77 & 2,910 \\
\hline & 壳 & 吕 & （億ドル） & - & - & 1 & - \\
\hline & & & & 16 & 41 & 6 & \\
\hline
\end{tabular}

上述のと呿り，石油化学工業と総称されるものはは なはだ規模の大なるもので，製品る多種多様にわたる から，とらていその詳細, 製涯な、どを述べ得ないので, 以下代表的なものについてその趨攀を述べてみよう。

(i) 鏆式誘筫体

鋇式誘導体の原料としては，天然ガス，副茛的な製 油所ガス，特に製造した各種オレフィン類をはじめ， ワックスディスティレートに至るまで，石油中に含ま れるあらゆる鎻式化合物が用いられている。

まず天然カ゚ス中に最む多量に含有されるメタンは， いわゆる×タンクラッキングにより水素の製造に向け られ，合成アムモニア工業，硬花油工業などの水素源 となつている。ホたメタンクラッキングの際に使用す る水蒸気量を適宜調節することにより，生成する水素 と一酸化炭素の比を調節し, メタノール合成やフィッ シャ一合成疦, ハイドロコール洗, オキソ法などの原 料としている。

このハイドロコール泿は最近テキサス州ブラウンズ
従来の資源

現在石油源の割合

石 炭 水素の $45 \%$

木材, 石炭然ガス俞ら約80\%(1949)

糖蜜, パルプ廃液，殸類なぞ $57 \%$

糖蜜，澱粉醱醭

フーゼル油

油 脂 類

石炭

糖留

カーバイト

石炭

石炭
$100 \%$

少なくをを $35 \%$

$90 \%$

$16 \%$

$7 \%$

$90 \%$

少量, 將来塔加

$60 \%$

$80 \%$

ヴィルで実施され，ガッリン，デーゼル油を生竰し， アルコール類, アルデヒド類, ケトン類, 有機酸類を 副艮するものであるが，その成果は注目されている。 オキン法は 3 会社により実施または計画中であり，主 成品はインォクチルアルコールで，洗深刘の原料とな る。

メダンから製造されるもののらち，量的に最も多い ஆのはアムモニアで急速に增加しつつあり，ついでメ タノールであり，1946年には石炭源のものが71\%であ つたが，1948年には天然が ス源のものが77\%，1949年

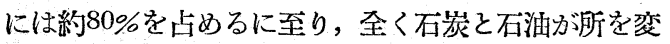
えている。メタノールの80\%はフォルムアルデヒド に,フォルムアルデヒドの大部分はベークライトの原 料になつている。

エタン，プロパン，ブタンなどはいわゆるドライガ スであつて,回收して揮発油として使用し得ないので， クラッキングまたは脫水素反応によりオレフィンとし て石油化学の原料に向けられる。おた，これらのガス を空気により直接酸化して，アルデヒド，アセトン， アルコール，脂肪酸などの製造がアメリカ・セラニー ズ・コーポレーションなどによつて実施されている。

オレフィン類は反応性に富むゆえ最も有用な石油化 学原料であるが，石酒源から㮔々の方法で得られるオ レフィン類の消費量を第 3 表に示す。

第 3 表から明らかなるごとく，オレフィンの消費量 の霄加は 5 年ごとに約 2 倍であり, むつて石油化学工 業発展の跡をしのぶことができよう。 
第 3 表 石油化学工業のオレフィン消費量 (単位 $1,000 \mathrm{t}$ )

$\begin{array}{ccccccc}\text { 年 } & \text { エチレン } & \text { プロピレン } & \text { ブチレン } & \text { イソブチレン } & \text { 許 } & \text { 倍 } \\ 1941 & 195 & 104.5 & 20.4 & - & 319.9 & 1 \\ 1945 & 350 & 208.5 & 167 & 65 & 790.5 & 2.5 \\ 1950 & 698 & 401 & 411 & 53 & 1,563 & 4.9\end{array}$

\begin{tabular}{|c|c|c|c|c|c|c|}
\hline 4 表 & $\begin{array}{c}\text { 石油化学坓 } \\
1950\end{array}$ & 品別エ三 & ン消費車 & 1962 & & (単位 1,00 \\
\hline 製品量 & $\begin{array}{l}\text { エチレン } \\
\text { 所要量 }\end{array}$ & & 製品量 & $\begin{array}{l}\text { ×チレン } \\
\text { 所要量 }\end{array}$ & $\%$ & 篕加率 \\
\hline 219.5 & 219.5 & 31.4 & 508 & 508 & 28.3 & 2.3 \\
\hline 321 & 225 & 32.2 & 719 & 505 & 28.1 & 2.2 \\
\hline 245 & 78.6 & 11.3 & 561. & 182 & 10.1 & 2.3 \\
\hline 159 & 62.2 & 8.9 & - & 159 & 8.9 & 2.6 \\
\hline- & 40.9 & 5.9 & - & 91 & 5.1 & 2.2 \\
\hline- & 13.6 & 2.0 & - & 22.7 & 1.3 & 1.7 \\
\hline 25 & 25 & 3.6 & 250 & 250 & 13.9 & 10 \\
\hline- & 33.2 & 4.7 & - & 77.3 & 4.3 & 2.3 \\
\hline - & 689 & 100 & - & 1,795 & 100 & 2.6 \\
\hline
\end{tabular}

第3 表の弓ち最も消費の多いェチレンの，用途別に 特ける過去呿よび今後の予想を示せば, 第4 表と和り である。

すなわち，過去 10 年間の增加がほぼ 5 倍であつたの に比し, 今後 10 年間の增加は約々の牛分 2.6 倍と推定 されている。しかし量的にいえば，1941年当時の石油 化学工業発祥後間むないころに比して過去10年間の增 加率の大きいのは当然であるが，さらに今後 10 年で既 に有機化学製品の $25 \%$ を占めている現在の 2.6 倍に躍 進することが予想されているのは警くべきことであ る。

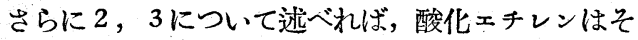
のままでも消毒倣，殺菌㧩として用いられるが，大部 分はェチレングリコール，アクリロニトリルなどの製 造に向けられる。ェチレングリコールの全製蓙量は， 1941年 68,800 tであつたが，1950年には 232,000 t に 達しており，現在ではその大部分が石油化学製品であ る。用途は不涷剮，爆薬エチンングリコールヂニトレ 一トの原料, グリセリンの不足によるその代替品, 最 近合成繊維界に登場したダクロンの原料などである。

またェチレンから誘導されるアクリロニトリれを原 料とする合成纎維にはオーロン，アクリラン，ダイネ 几などがあり，ェチレン系合成繊維の全製造量はほほ ナイロンに必敵し，それぞれレイョンの約 10 分の 1 に 達している。

エチルベンゼンは，エチレンとベンゼンの附加反応 により生成され，さらに脫水素してスチレン $\left(\mathrm{C}_{6} \mathrm{H}_{5}\right.$. $\mathrm{CH}: \mathrm{CH})$ とする。スチレンは合成ゴム GR-S および
プラスチックの原料である。スチレンの生產は, 1939 年 45,000 t から 1950年 $245,000 \mathrm{t}$ に激增しているが， その用途は戦時中は主として合成ゴム, 戦後は合成ゴ ムからプラスチックスに移りつつあり，既に後者の所 要量は前者のそれを淩鴐しているといらことである。

二篮化ェチレンはェチルフルード, 瑥化ビニールの 原料,二臭化ェチレンはェチルフルードに用いられる。 ポリェチレンは一種のプラスチックであるが，低溫 でももろくならないという他のプラスチックに全くみ られない特性を有し，且つ原料か洝価であるから，將 来最むのびるものであろら。從来重要な用途は電気絕 緣材であつたが，現在は冷凍食料包裝紙，フィルムに その半量が使用されている。

プロピレンはエチレンに比して從来あまり重要でな かつたが，最近グリセリンの原料としてきわめて重要 なものとなつた。な特,この他プロビレンオキサイド， プロピレンポリマー，プロビレングリコールなどとし てプラスチック，デタージェントなどに向けられてい る。

またベンゼンとプロピレンの附加反応によりキュメ ンとし，これを酸化しさフェノールとアセトンを得る 方法が最近注目されている。

ブタン，ブチレンはそのままアルキレーション， イ ソメリゼーション，重合などによりイソォクタンの製 造原料となるが，ポリブテンとしてデタージェント， 潤滑剤に，ブタジェンとして合成ゴムの原料に使用さ れている。この中最も主要なものは GR-S であり， ブタジェンとアクリロニトリルから合成されるニトリ 
ルゴムも耐油性ゴムとして重要である。

高級オレフィンもまた石油化学原料として使用され ており，中でもワックスを分解重合させる高級潤滑油 製造涯，ワックスを分解，スルフォン化してデーター ジェント（シェル・ケミカル社ティポール）などにす ることはよく知られている。

上述のようにォレフィン，なかんずくェチレンは最 も重要な石油化学原料であるが，最近着目されている ものに石油化学系アセチレンがある。これは，レッぺ 化学の発展により，その原料源として注目されたもの で，この製造法としては，從来のカーバイトからする ものと，天然がスからするものとあるが，前者は電力 輸送などの制約を受けるので特定地域以外では困難で
あり，発展も扔のずから局限されると思ら。後者子種 々制約を受けるが,カーバイトに比し有利であるから， 天然ガスに惠まれている米国では，技術的難点が解決 きれれば飛躍的発展を逐げるものと思われる。

現在,天然ガスからアセチレンを作る方法としては， 主としてドイッで発達した Schoch 法, Sachse 法, 空気酸化法，Wulff 涯などがあり，精製法としては， セロソルブ，アセトン，グリコールフルフラールなど を使用する溶㓮抽出法，ハイパーソープション泿など があるが, 得られるガスの純度により方法も異るので， その比較を第 5 表に揭げる。これによれば，米国では Wulff 法とハイパーンープションの結合したものが最 も有利であるが，まだ試験装置を出ないようである。

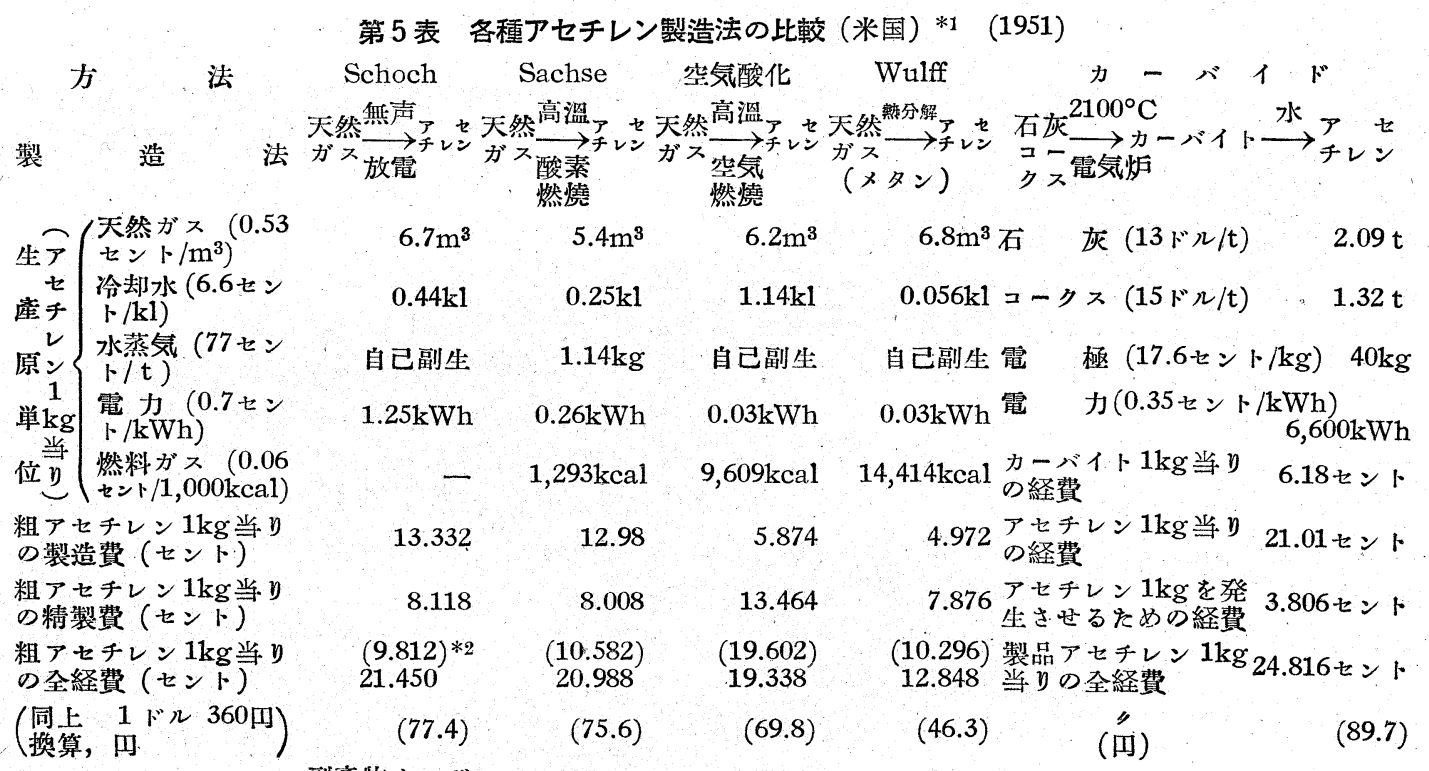

長

短

副虐物カー

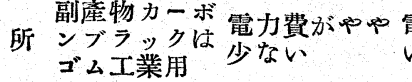

所 以上バイト電力を酸素製造設借 要す
電力少なく
エチレンン゙る゙

*1. アセチレン年產量 2,000 万1b $(9,100$ t) カーバイト(純度 $80 \%$ ) 年產量 $31,000 \mathrm{t}$ として計算。

*2. 精製費はすへてハイパーソープション法による。（）內は溶剤抽出法による場合。

アセチレンの用途はほぼェチレンと同様であるが， 1949年にはポリ醋酸ヴィニルが $9,700 \mathrm{t}$,ポリ塩化ヴィ ニル拉よび塩化ポリヴィニリデン $17,200 \mathrm{t}$ が生產され た。その他ヴィニルアセチレンに塩酸を附加重合さて 得られる合成ゴム,ネオプレンの生制能力は年 $60,000 t$

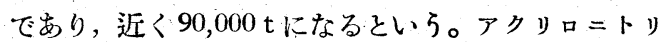
ルもまたアセチレンから得られるが，現在生產してい るのは一社で, 年間 $1,200 \mathrm{t}$ の能力である。またブナ
N型のゴム，アセトアルデヒド，醋酸，無水醋酸，八 ロゲン化製品などの製造原料となる。

將来, 天然ガスからのアセチレン製造が工業化され ても，同じく石油化学工業のひとつであり，おそらく 両者は併立してそれぞれの長所を生かす方向に進むで あろらと予想される。

(ii) 芳香族誘導体

石油中に含まれる芳香族の量は，沸点の上昇ととも 
に增加するが，揮発油溜分では通常10\%以下，まれに 30\%に達するものもむる。この石油中の芳香族は，か つて灯油時代には煤煙の原因となるので，また揮発油 時代に移つてからもオクタン洒は高いがェンヂンの気 筒溫度が上昇し過ぎ，発熱量が低く，またべンゼンの 㠜固点が高いなどの理由で，望ましからざる成分とさ れていた。この芳香族を除くため最初に工業化された のが，液体亞硫酸を溶肪とするかの有名なェデレアヌ 沄である。その後航空機が発達し亞成層圈飛行を行 万 よらになり，蒸気压の低いいわゆる安全燃料，与なわ ち芳香族燃料が重要視されるようになり，石油中に含 まれる芳香族は必要物として抽出されるに至つた。一 方，前大戦中爆薬原料としてのトルェンが極度に不足 し，その補充源を石油中のトルェンに求めた。以上の ように，石油中の芳香族は燃料としてもその重要成分 そなり，また有穖化学工業の芳香族源としても重要親 されるに至つた。

以上の理由から，石油中の既存の芳香族定抽出，混 合するといら簡単な物理的の方法のほか，その芳香族 含有量を化学的に增加させよ 5 とする研究が，1930年 ごろから盛んに行われた。すなわちパラフィン系炭化 水素を脫水素し，環化せしめる方法が発達し，アロマ チゼーション，サイクリゼーション，少イクロヴァー ションなどの述語が生れた。工業的には気相分解法, サーマルリフォーミング，次いでキャタリチックリフ オーミングなどか浣成された。また石油中のナフテン 炭化水素を脫水素し芳香族化する種々の触媒力゙研究さ れ，ハイドロフォーミング，プラットフォーミング， フードリフォーミングなどが完成された。中でも最も 注目されているのはプラットフォーミングで，これに は高オクタン価然料の生应を目標とする場合と，芳香 族生茛を目標とする場場合と, 運転法には二様あるが， わが国でも既に各社で高オクタン価燃料の生產を目標 に $1,500 \mathrm{bbl} /$ 日 規模の建設に着手している。

以上，芳香族の化学生栍が可能になるとともに，こ れが分離法も相伴い急速に発達し，前述のディステッ クス法 (抽出蒸溜法)，アロソーブ法ニデックス泆な どが完成された。

以上が石油を原料とする芳香族生栍方式の大要であ るが，これを米国の生虐からみれば，ベンゼンの全生 蒦量は 1941年約 135,000t/年であつたが，戦爭と共に 急增し，44年江最盛期に達し，穴の量も約 $530,000 \mathrm{t}$ となり,戦争終結と共にやや減少したが再び上昇し, 50 年には44年を上迴り約 635,000 $\mathrm{t}$ に達した。しかし, 50 年度に特いてさえわ，石油系ベンゼンはまだわずかそ
の10\%にも充たない。1951年の推定生產量は 650,000t 前後で，1955年には $1,700,000 \mathrm{t}$ のベンゼンが生栍さ 凡，その $50 \%$ 弱が石油から生產されるるのと推定され ている。ベンゼン生竟の飛躍的墂加もさることなが ら，石油を原料とするべンゼン生產量は，1950年の約 $60,000 \mathrm{t}$ から1955年の約 $800,000 \mathrm{t}$ 一と10倍以上に上 昇寸る見込みである。この $800,000 \mathrm{t}$ のベンゼンを生 栍するに必要な揮発油量は，天然ガンッンを含めて全 揮発油量の約 $0.5 \%$ に過ざないと予測されて招り，從 つて燃料としての揮発油所要量を和びやかすことな く，さらにベンゼンは墙莲されるであろらが，かくの ごとく石油系のベンゼン生崖量の急增が今後の問題で あることは，上述の誯法の工業化あるいは工業化の見 透しがごく最近なされたことを物語るるのである。

ペトロケミカルズとしてのベンゼンの主用途は，エ チレンと区応させて得られるスチレン，またはプロビ レンと反応させてキュメンとし，これを酸化してフェ ノール，アセトンを製造することなどである。

石油系トルェンは，1943年の約 $400,000 \mathrm{t}$ （政府生 犀を含まず）をどークとし，1944年には約 $300,000 \mathrm{t}$ に怙ち，さらに1946年にその1/10にまで低下したが， 再び漸增し1949年には $150,000 \mathrm{t}, 1950$ 年には230,000 t まで恢復した。その主用途は T.N.T. であるが，ち なみに1944年における航空揮発油用トルェンの量は 110,000 tであつた。

石油系キシレンは 1944年約 160,000 tで，トルェン 同様漸減し，1947年には $110,000 \mathrm{t}$ までおちたが，そ の後再び增加しはじめ，1949年には1944年をやや上迴 る程度に, 1950年には 195,000 t に達した。この主用 途は無水フタール酸,テレフタール酸として可塑滆に, あるいは合成纎維ダクロン，テリレンに向けられる。

石油系トルェン，キシレンの將来の生量は不明で 离るが, 石油系ベンゼンの堙崖により副生し, しかも 芳香族化されるナフサ溜分中のトルェンー転換される ナフテン量はベンゼンへ転換されるそれの約 2.5 偣， キシレンのそれは約 3 倍以上にも達するといらことで あるから，必要量のトルェン，キシレンを得ることは 容易であろら。

な招，前述の分離法によつてナフテン族も分離され でり：シクロへキサンはナイロン原料のアヂビン酸 として使用されている。

(III) 石油工業と石油化学工業との比較

前述のように，石油工業と石油化学工業とはきわめ て密接な関係があるが，現在米国ではほぼ両工業は独 立し，石油工業は石油化学工業の原料をたは一次製品 
を生產しているようである。

米国に打ける石油化学製品生產会社は，1935年〜36 年にはわすか 1 社に過きなかつたか; 40 年 5 社, 41年〜 43年24軏，44年48社に達し，以後の習加は少なく，49 年61社に達した。

その規模は石油工業裝置の約 $\mathrm{x} / 8$ ，資本は $1 \mathrm{kl}$ 当り

石㹨工業の約 3 倍てまるといろ。すなおち，石油工業

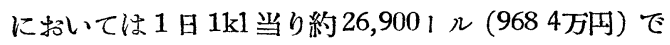
あるか，石油化学工業ては 1 日 $1 \mathrm{kl}$ 当り約78,5001 (2,826万円) ている。

両者の 1950年度に打ける利㿽率は次表のと招りで ある。

\begin{tabular}{|c|c|c|c|c|}
\hline 会 社 数 & 納稅後の実收 & 資 & $\begin{array}{l}\text { 資產に対す } \\
\text { る利潤 \% }\end{array}$ & $\begin{array}{l}\text { 販壳に対する } \\
\text { 利益率 } \%\end{array}$ \\
\hline 石油化学会塗 65 & $742,513,000$ ドル & $3,484,916,000$ ドル & 213 & 117 \\
\hline 会社 45 & $1,730,484,000$ リ゙ル & $11,618,635,000$ レル & 149 & 108 \\
\hline
\end{tabular}

研究費は石油工業ては全売上高の約 $085 \%$, 石抽化 学工業ては他の化学工業と同しく約 $22 \%$ といらこと てある。

なお，副資材所要量比は次のと括りてある。

石 油工場 $\begin{array}{cccc}\text { 燃 料 } & \text { 水蓀気 } & \text { 電 力 } & \text { 水 } \\ 1 & 1 & 1 & 1 \\ 10 \sim 20 & 3 \sim 10 & 3 \sim 10 & 10 \sim 100\end{array}$

石油化学工場

また位置と製品輸釜の問題は大きな問題てあるが， 製品運㑯は次表のよ 5 に石油製品の約 2 倍になる。

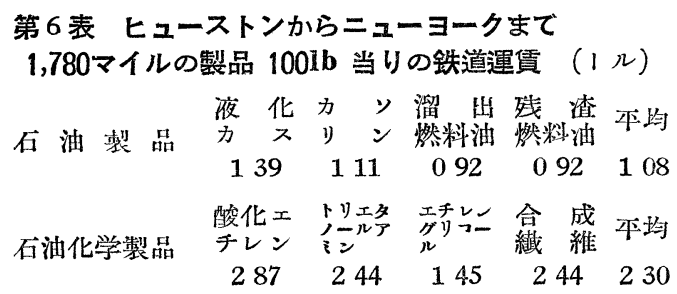

以上数字を羅列したに過きないか，もつて石泊化学 工業の規模を知る好個の参考であると思う。

石油工業は動力原としての大量の製品を $\mathrm{kl}$ 単位て 取扱 5 品種の少ない工業てあるか;, 石油化学工業の最 終製品の多くは $\mathrm{kg}$ 単位て, 薬品市場て要求される種 々の等級の無数の品種か必要てあり, むたその純度, 拝性, 仜険性なとに関しても考慮せねはならない。こ のことか石油工業と石油化学工鄴との根本的な相違 て，企業体勢を整えるに当つては，原料，製造技術の 研究, 新種㱔品の市場調查, 特許権なとを入いに洘慮 せねはならないと考える。

\section{(IV) 結}

\section{言}

われわれは，戦後ます米国，次いて欧州の状況を知” り,その石油化学工業の発展の目覚ましさに警き,これ に対して個人も各工業会社もともに非常に鬽力を感し ているか，石油化学工業は, 米国においても斬くその 緒についたはかりて，しか子その分野の広䜑なこに 思い至し，ひるかえつて戦前にさえ復㽚していない
わか石油工業をかえりみるとき，軽々に石油化学工業 䘮論し得ないと思う。

上記の数字かそのまま比例的にわか国に当てはまる とは考えられないか，一握千金的な工業ては決してな いことを認識し,かつ企画を誤たなけれは戦前の重合, アルキレーション，メタン执よびパラフンクラノキ ンクなとの技術経験を有するわか石油工業界にとつて は，技術的には石油化学工業はあなかち夢てはなく， プラノトフォーミングもここ1，2年のちちには完成 されるてあろらから，既に石油化学工業への第 1 步を 踏み出したものといつてよく, 今後さらに母体石油工 業の発展, 瀻維, 肥料なと有機合成工業の技術的発展 そそれらの企業的協力に支持を受けて，石油化学工業 への磪実な途を闒くことか，本邦化学工業の將来へ寄 与するものでると考える次第でる。

筆を打くに当つて，いま一度石油化学工業への警告 を引用し，私見を加えて参考に供したい。

（1）石油化学工業を企画するに当つて何より重要な ことは，工業的単位を知るための製品の規模と価格 を推計学的市場調查によつて推定することてある か，これは重化学工業としての見地から，医内はも ちろんのこと, 需点苍輸出工業としての市場調查て あらねはならない。

（2）市場の蒦得のためには製造方法の改良による価 格の引き下げより，良き性能を有する新製品の探究， および用途の開拓かたいせつであつて，本工業の最 も重要なことは基本的研究てある。多額の研究費を 投して，米国より一步先んするまての計画的な研究 を逐行し得る企業力と,レッぺ博土に劣らぬ信念と 努力かなけれはならぬ。

（3）工埸立地の條件としては, 原油を輸大する以上, 石油製品および化学製品の販売に有利な地点, 最終 痟費者と中間物として関速迹業へ供給する場合とを 都慮して，販売に有利な地点を選はねけならぬ。す なおち，化学製品の輸䢒費は石油製品の $2 \sim 3$ 倍に 
なるので探算に大きな影響を持つ。また副資材とし て莫大な水，電力を要すること，酸，アルカリ工業 その関係が立地選定の要因ともなる。

（4）石油化学工業の研究の方向としては, 石油工業 看当者は原料の物理的衫よび化学的分離法により成 分の分離と純度をあげることがまず第一であり，第 二に分解，重合による変成，改質を行らにあり，ま た化学工学的な，連続様式による経験を有機合成反 応に持ち込み, 操業の正確さと能力の增進による收 率向上に寄与し，一方有穖合成化学担当者は低廉な 有機原料を基盤とした新しい製品とその用途の開拓 研究にその合成技術（石炭化学，アセチレン化学， 繊維化学など）の経験と智力を生かして，おのお のその分野に邁進すべきであり，本邦工業化学耪智 の遊びこそ最大のロスであることを，化学工業行政， 経済, 経営の指導者か理解されんことをせつに願ら 次第である。

往々，既設工業は研究費をかけるより特許料を支 払ら方が有利であるといわれるが，戦時中の空白を 取戻すためと，わが国の弱点である化学工学的単位 技術を輸入することは手段としては意義あることで あるが，石油化学工業のよ5に進步に速度のあるも のの場合にはそれ以上の何物でもないこと，明日に 備えなりれはならないことを考えれば，研究の重要 ささは銘記せねばならぬことである。

（5）わが国石油化学工業の段階としては,

（i）原料的に惠まれないわが国では，原料として
は製油所ガスのうち分離精製が容易であり,且つ, 経験のあるプロパン，ブチレンから出発するのが 妥当ではなからろか。この場合アセトン，ブタ， ール，オクチルアルコールなどが一次製品として 考えられる。灯, 軽油の成分分離, ワックスなど からの洗刜も考えられる。また天然がスからアム モニア，メタノールなどを製造するの子原料獲得 に対する調查か確実であればよいと考えられる。

（ii）石油化学製品の市場調查が十分でない現状で は，纎維などを対称とするェチレン工業への出発 はしばらくアセチレンエ業にゆずり，燃料の背景 があるプラットフォーミングによる高オクタン価 揮材の製造に着手したことは当を得たものという ベく, ベンゼンの生星過剩が將来も続くとは思 えないから，時至れば，ニド,クス法その他を 併設して芳香族生產に移行すればよい。次いで石 炭酸々醋酸が廉価に供給できる見透しがつけば， これらを原料とする合成纎維の要求により石油化 学工業も第2 段階一大るものと思われる。なお, エチレン，アセチレン分野への進出は，これらの 分解精製技術の化学工学が確立されたときがよい のではあるないか。そのときを期して新合成製品 を出すことを研究の第一主義とせねばならないと 考える。な扔，云い特としたことで，鎻式化合物， 芳香族化合物は既にかなり発展しているが，ナフ テン族化合物の利用の研究も今後の問題として非 常に興味あることを附言する。

\title{
Industrial Development in Petrochemistry
}

\section{By Haruji Yamamoto}

(The Mitsubishi Oil Co.)

\begin{abstract}
SYNOPSIS :-A historical survey of the petrochemistry in the United States is presented with detailed descriptions of the properties of the petrochemical products as well as recent consumption of raw materials and producing capacity. A brilliant future development is expected of the petrochemical products which have already taken important parts in the organo-chemical industry. Its applications to the Japanese industry are, however, to be circumspectly considered mainly for the point that the postwar situations of Japan's petroleum industry are apparently different and backward from the countries referred in this review. The author's project of the possible development in Japan is suggested.
\end{abstract}

